\title{
Research on Flipped Classroom Teaching Mode Based on MOOC_-Taking Physical Education Teaching in Higher Vocational Colleges as an Example
}

Yating Huang

Xinjiang Agricultural Vocational Technical College, Jichang 831100, Xinjiang, China.

Abstract: With the continuous progress and development of modern society, all aspects of people's life have undergone earth shaking changes, especially the comprehensive popularization of information technology at this stage, which makes the quality requirements of various industries have been improved to a certain extent, including in the field of education. Therefore, in order to better adapt to the development of the times and respond to the comprehensive call of education reform, higher vocational colleges should properly combine the development situation of modern society, formulate more timely teaching planning, so as to promote the construction quality of related courses teaching, and achieve teaching objectives more quickly.

Keywords: MOOC; Flipped Classroom; Higher Vocational Physical Education; Teaching

The integration of information technology and physical education curriculum is to create an information-based teaching environment by effectively applying information technology to physical education teaching process, so as to realize a teaching and learning mode characterized by "autonomy, exploration and cooperation", ${ }^{[1]}$ which can not only play the leading role of physical education teachers, but also fully reflect the dominant position of students. It greatly stimulates students' interest in learning and enthusiasm, so that students' own initiative can be better improved, meanwhile it also truly reflects the practical value of innovative teaching in essence. Even though the rapid development of information technology provides teachers with more diversified ways to carry out teaching, from the practical point of view, it also brings some challenges.

\section{The current situation of physical education in higher vocational colleges}

As far as the actual situation and effect of physical education teaching in higher vocational colleges is concerned, there is still a big gap between it and the actual training demand of applied talents in modern society. Most colleges and universities still do not have a comprehensive understanding of the importance of physical education course teaching for students' future development. Lacking of pertinence in the course planning, there are quite a log of unreasonable course setting and allocation by teachers, and in the process of physical education teaching, they still use the traditional single passive indoctrination teaching mode, more focus on the accumulation of students' professional knowledge, and do not pay enough attention to practical teaching, so that the extremely low interest in learning and weak physical exercise awareness make it difficult to effectively improve the enthusiasm of students' autonomous learning, greatly reducing the quality of physical education teaching.

Secondly, teachers do not combine the reform requirements of physical education in the new era in real time, to a certain extent, lacking of more innovative teaching methods is difficult to effectively meet the actual learning needs of students. Moreover, teachers pay too much attention to theoretical teaching and ignore the effective cultivation of students' professional

Copyright(C 2020 Yating Huang

doi: 10.18686/ahe.v4i10.2959

This is an open-access article distributed under the terms of the Creative Commons Attribution Non-Commercial License (http://creativecommons. org/licenses/by-nc/4.0/), which permits unrestricted non-commercial use, distribution, and reproduction in any medium, provided the original work is properly cited. 
application ability, which makes students do not have strong sense of professional identity for physical education. Some physical education teachers' thinking mode is relatively fixed, they are not willing to develop more efficient teaching mode with the times, and results in weak ability of information technology literacy, which is one of the reasons for the low learning effect of physical education curriculum in higher vocational colleges.

\section{The practical significance of flipped classroom teaching mode based on MOOC to physical education teaching in higher vocational colleges}

With the rapid development of information technology, human beings are stepping into the information society from the industrial society. With the advent of the information age, the rapid development of multimedia technology and network technology has a strong impact on the contemporary educational ideas, concepts, models, methods and means. The deep integration of information technology and physical education teaching is the fundamental goal of the integration of information technology and physical education curriculum, and it is also the inevitable of the development of education informatization ${ }^{[2]}$. Therefore, teachers in the process of physical education teaching, the appropriate combination of information technology with flipped classroom teaching mode can not only better mobilize students' learning enthusiasm, make them more actively participate in physical exercise, and more quickly achieve teaching objectives, but also through the in-depth integration of information technology and physical education, break the limitation of traditional teaching in learning time and space. It helps students more comprehensive understanding of the importance of physical exercise, better develop good habits of physical exercise, meanwhile teachers can use the super high advantage of flipped classroom to create a more harmonious and interesting teaching atmosphere, in order to fully mobilize students' classroom concentration, and effectively improve the physical education curriculum teaching quality and efficiency. In addition, under the environment of MOOC innovative teaching, teachers can make more targeted practical teaching plans, strengthen students' practical application ability, and improve students' physical health quality, so as to fully show the main role of students, and improve teachers' information literacy in real time.

\section{Application of flipped classroom teaching mode based on MOOC in higher vocational physical education}

\subsection{Innovative teaching mode}

"The integration of information technology and physical education teaching" has brought a great change to physical education teaching, which makes the time and space of physical education teaching no longer limited, and the physical education teaching environment has been extended to a certain extent ${ }^{[3]}$. Therefore, teachers can make full use of information technology teaching, on the basis of MOOC resources teaching, and constantly adjust the teaching planning and direction of physical education curriculum knowledge. According to the training requirements of modern society for applied talents, formulate a more scientific and reasonable teaching curriculum system, and gradually establish a teaching resource library with higher teaching effect. In the process of physical education teaching, teachers in higher vocational colleges, the teaching resources that are more suitable for students' learning psychology in the high-quality information teaching platform are firstly selected. For some complex movement structures, they can demonstrate by playing interesting animation or short video to help students better understand the core of corresponding movement training to deepened the impression for students, at the same time, it stimulates students' desire for knowledge, fully mobilize students' classroom attention, so as to more effectively improve the quality and efficiency of classroom teaching.

Secondly, teachers can push the corresponding video teaching before class, so that students can watch independently and record the relevant problems of the course related knowledge teaching in real time, and encourage students to try to solve them by consulting the data relevant to the problems independently. In the daily course teaching, teachers can collect all kinds of questions of students and give answers by the targeted questions. In this way, students' autonomous learning ability can not only be more effectively improved, but also can complete the accumulation and application of physical education curriculum knowledge anytime and anywhere according to their own learning needs, which greatly improves the actual learning efficiency of students. 


\subsection{Improving teachers' information literacy ability}

Physical education teachers are the main force to realize the integration of information technology and physical education. Therefore, it is necessary to strengthen the information technology ability of physical education teachers, so that they can master and use information technology and grasp the pulse of information technology development. First of all, higher vocational colleges should be fully aware of the quality construction of teachers, which plays an extremely important role in improving the actual effect of physical education teaching. Higher vocational colleges can make more targeted training plans according to the information literacy ability of teachers at this stage. By strengthening information application ability, teachers' self-confidence in information application teaching can be effectively improved, in order to participate in the innovation of information-based teaching mode. Colleges and universities should timely improve and adjust the teaching evaluation mechanism, and promote teachers' innovative teaching thinking, so that teachers can carry out more in-depth exploration and research with students according to the actual teaching effect of flipped classroom, achieving common progress more quickly.

Secondly, teachers, who are in the continuous improvement of self-information literacy, can better grasp the learning rhythm of sports professional flipped classroom, so as to carry out the teaching work of sports professional curriculum knowledge more effectively. In the daily curriculum planning of physical education major, teachers can learn and train the relevant actions of the course content first, and reasonably combine with the corresponding information technology to edit the teaching video with more pertinence, so as to complete the improvement and optimization of the course content planning step by step, which can not only help students understand the action training more intuitively about the main point, but also gradually strengthened teachers' information literacy ability.

\subsection{Construction of flipped classroom teaching and training base based on MOOC}

In order to further implement the flipped classroom teaching, higher vocational colleges should carry out practical teaching for physical education teachers and build training bases so that students and teachers can carry out flipped classroom teaching in the training base. At present, online learning video before class is not the same as simple preview, and micro video is not courseware. In actual teaching, only by building professional teaching and training base in higher vocational colleges can we ensure the success of micro course design, guarantee the interaction between students and teachers, participate in the production and design together, and truly benefit teachers and students for better learning.

\section{Conclusion}

In summary, as a basic major to ensure the healthy development of students' physical and mental health, teachers should not only pay attention to students' accumulation and application of sports professional knowledge in real time, but also adopt a more innovative flipped classroom teaching mode to help students more fully realize the practical significance of sports curriculum knowledge for their future development in order to actively participate in physical exercise activities.

\section{References}

1. Sun Z, Xin D. Experimental research report on college physical education teaching mode based on information environment. Education Time and Space 2013; (11): 109.

2. Peng C. The effective application of information technology in junior high school physical education. Sports Science 2014; (6): $83-85$.

3. Tong D. Research on the mode effect of the integration of information technology and physical education. Adult Education in China 2007; (10): 147. 